Reeve, D. (2012) 'Preparation for practice: Can philosophy have a place in helping students incorporate the social model of disability within their praxis?', Social Work Education 31(2): 227-34.

This is the corrected version incorporating reviewer comments and has been paginated to match the published version. Small typographical differences may therefore exist between this and the published version.

\title{
Preparation for practice: Can philosophy have a place in helping students incorporate the social model of disability within their praxis?
}

\begin{abstract}
This short paper emerges from an engagement with the paper by Morgan in this special edition which argues that the social model of disability can be viewed as a threshold concept which students struggle to 'get'. I suggest that introducing social work students to philosophical concepts such as recognition at an early stage of their learning about skills, values and anti-oppressive practice, could facilitate the transition over this disability studies threshold, reducing the potential for ritualised performance instead of true understanding. It will be argued that Honneth's account of recognition in particular can be helpful in reducing the risk of psycho-emotional disablism within professional relationships between social work students and disabled service users. However I also suggest that encouraging students to engage with philosophical questions about personhood and humanity are crucial to maintaining true anti-oppressive practice at a time of financial cutbacks in social work services.
\end{abstract}

Key words: disability studies; psycho-emotional disablism; social work education; Honneth; recognition

\section{Introduction}

This short discussion piece is informed by several events: teaching various groups of students about psycho-emotional disablism, the framing of the social model of 
disability by Morgan (2012) as a threshold concept, as well as an introduction to the philosophical concept of recognition (Honneth, 1995). Consequently I want to explore how the introduction of some basic political and social philosophy to social work students at an early stage in their learning might smooth the subsequent passage of incorporating the social model of disability within their social work practice. In particular, I consider the ways in which discussions about recognition encourage the development of 'integrated understandings' rather than 'ritualised performances' of the social model described elsewhere in this special edition by Morgan.

\section{Axel Honneth: Recognition, respect and esteem}

Philosophy at first glance, is not an obvious bedfellow for teaching social work practice. In the months leading up to the social work symposium I had been introduced to the work of Axel Honneth who is a social philosopher. In his book The Struggle for Recognition (1995) Honneth draws on work by Hegel, Mead and Winnicott to develop his critical theory of recognition which places emphasis on the importance of recognition within all human interaction. For Honneth, social justice depends on recognition which takes three different forms:

- 'Love': Close relationships with family and friends which involve mutual dependence (Honneth, 2001). Recognition at this level develops selfconfidence at both the emotional and body level.

- 'Rights': Being recognised as a citizen and enjoying civil, political and social rights which promote self-respect.

- 'Solidarity': Freedom from denigration and being recognised as valuable to society. Having one's unique talents or capabilities recognised in this way promotes self-esteem.

An individual needs to be recognised in all three spheres if they are to achieve 'selfrealisation', or in other words, 'the unforced pursuit of freely chosen aims in life' (Honneth, 2001: 50), unhindered by external pressures as well as those that operate at the individual psychological level such as inhibition or anxiety. However, when a lack of recognition takes place, or in other words, when misrecognition and disrespect occur, then humiliation, shame, indignation and other harmful emotions may be experienced. Forms of misrecognition include exclusion, insult or degradation.

Within the field of social work, it is only relatively recently that Honneth's theory of recognition has been applied to social work practice (see for example Houston, 2009; 2010; Houston and Dolan, 2008; Juul, 2009; Marthinsen and Skjefstad, 2011). Marthinsen and Skjefstad (2011) provide a useful discussion of how 'love' in social work terms may be translated into 'trust', requiring that the relationship between social worker and the person they are supporting needs to be based on authenticity and unconditional caring. Writers such as Garrett (2010) have eloquently discussed some of the weaknesses of Honneth's work - in particular the downplaying of the role of the state in (re)creating divisions and social oppression in favour of interpersonal 
relationships. Therefore Garrett would promote the work of Nancy Fraser who places more emphasis on redistribution alongside recognition to achieve a parity of participation, as opposed to Honneth who argues that love, respect and esteem are necessary conditions for social justice (see Thompson, 2006). Nonetheless it is acknowledged 'that there is still a case for embedding the politics of recognition into social work education and practice' (Garrett, 2010: 1527).

\section{Teaching students about psycho-emotional disablism using Honneth}

Whilst Honneth does not directly address the issues faced by disabled people in society, several writers within disability studies have used Honneth's concept of recognition as a way of trying to reconcile the individual and collective experiences of oppression (see for example Abberley, 2002; Shakespeare, 2000; 2006; Watson, 2003). Danermark and Gellerstedt (2004) relate the three strands of recognition to the following issues specific to disabled people:

- 'Love': The fragile balance between autonomy and dependence which occurs within relationships between disabled people and their caregivers or personal assistants. The manner in which personal care is provided can affect someone's physical integrity, either supporting or undermining their bodily self-confidence as in the case of abuse.

- 'Rights': The fight by disabled people for full inclusion in society - at the political, social and civic levels - and the means to be able to exercise those rights.

- 'Solidarity': The stigmatisation of disabled people because prejudice has a direct impact on self-esteem.

My particular field of interest in disability studies is that of psycho-emotional disablism, in other words, looking at the disabling barriers which impact on the emotional wellbeing of people with impairments (D. Reeve, 2008). Structural disablism impacts on activity, for example when information is not provided in accessible formats or a wheelchair user is faced with a flight of steps, then that disabled person is prevented from doing something. In contrast, psycho-emotional disablism affects being, for example being stared at or patronised by strangers. Although the social model of disability does not deny the existence of disabling barriers which operate at the psycho-emotional level, in every day parlance the social model is generally used to identify and remove barriers which operate at the material, structural level. Internalised oppression and disabling interactions with others - all forms of psycho-emotional disablism - are acknowledged in passing but then overlooked in the face of more immediate structural barriers such as inaccessible transport and exclusion from employment and education. (For more information also see Thomas, 2007).

Because of the way in which psycho-emotional disablism is played out at the interpersonal level between disabled people and others (non-disabled and disabled), it is particularly important that professionals such as social workers understand how their behaviour and attitudes might (inadvertently or not) disable the person they are working with. Significantly, psycho-emotional disablism is cumulative like any form of 
emotional abuse (see D. Reeve, 2006). Consequently past experiences of being ridiculed or patronised may play out in current relationships with professionals; for example a disabled father may appear overly anxious about the care of his disabled son in a foster home, until one is made aware of the father's 'disability history' and his own past experience of abuse at the hands of a paid carer.

Another potential source of psycho-emotional disablism in social work practice can happen when disabled people step outside their cultural stereotype - for example a disabled women who falls pregnant which clashes with the prevailing image of disabled women as dependent, in need of care and asexual. Here is an example drawn from my PhD research (see D. Reeve, 2008) which reveals what happens when a disabled woman called Lucy, tells her social worker that she is pregnant.

Lucy: Yes, first response. 'Well, you know you can have a termination, we can arrange for you to have a termination' [said in mock patronising tone].

\section{Donna: And your response?}

Lucy: 'I don't want a fucking termination - I want a baby'. 'Yes, but how are you going to cope with things like changing nappies?' 'I'll find a way'.

Now that Lucy was impaired on one side of her body, the social worker failed to see Lucy as a potential mother and parent and instead assumed that a termination was the only solution. This comment haunted Lucy throughout the initial months of the baby's life and like many other disabled mothers, she worked hard to be the 'perfect' mother so that her baby would not be taken away from her (Thomas, 1997). It was only later that Lucy admitted her fears to a health visitor who reassured Lucy that she was a competent mother and that the baby would not be removed - Lucy felt supported by this health visitor and had a much healthier working relationship as a consequence.

It is clear that Honneth's theory of recognition can be used to illuminate the concept of psycho-emotional disablism; here Honneth's focus on interpersonal relationships is particularly appropriate when considering this inner form of disablism. Misrecognition occurs in the way that disabled people are less likely to be seen as potential employees than non-disabled applicants, disrespect is reflected in the mocking by a stranger of the different way someone walks. Misrecognition could also occur when someone has their benefits or services withdrawn because they are no longer recognised as being 'disabled enough' to qualify, leaving them as neither disabled or non-disabled but in a nebulous zone in between. Social work students, irrespective of their age, will all have had experiences of being misrecognised at some time or another in their life - from wearing the wrong clothes to a formal occasion, being bullied at school because of some perceived difference in body shape or being wolfwhistled at by a stranger across the street. Therefore they can understand at a visceral level the damaging effects of psycho-emotional disablism on the self-esteem of a disabled person.

Over the years I have had the opportunity to teach various cohorts of students on the Lancaster Social Work programme about psycho-emotional disablism. As Morgan (2012) eloquently describes in her paper in this special edition, whilst students can 
grasp the theoretical implications of the social model, they struggle to see how to implement it in real life situations. The social model is not only a 'threshold concept' to be grasped, but also poses very real pragmatic difficulties. Put simply - a student on placement may not be able to do anything concrete about a voluntary sector service which is housed in an inaccessible building (structural disablism). However, the student does have control over the manner in which they interact and support a disabled person, the attitudes and assumptions that they make (psycho-emotional disablism), which in turn influence the services provided. Structural barriers can cost money to remove and so have more in common with a politics of redistribution (see Fraser in Fraser and Honneth, 2003); in contrast the elimination of psycho-emotional disablism relies on the social work student to be reflexive and self-aware of their own prejudices about disabled people so that these are not acted out and so is commensurate with the politics of recognition advocated by Honneth.

Although social workers need to be aware of the impact that psycho-emotional disablism can have on the lives of people they are supporting, they also need to remain alert to the potential for (inadvertent) psycho-emotional disablism in the professional relationship itself between the social worker and the disabled person they are working with. This is one of the key points at which the student reveals how far they have 'got' the threshold concept of the social model of disability described by Morgan (2012), and where mimicry fails. For example, if a disabled woman becomes pregnant, does her social worker offer a termination as illustrated by Lucy's experience? Or does the social worker support access to parenting support classes? The response reflects, amongst other factors, the ability of the social worker to recognise the disabled woman as a potential mother.

\section{Implications for wider practice}

As I listened to the papers in the symposium, I mused on how this learning might be supported elsewhere in the curriculum, in other words, outside of the specific disability studies modules. Not surprisingly, my particular interest in psychoemotional disablism led me to consider ways in which students might be helped to 'get' this more private aspect of disablism. I now want to end by looking at the potential gains to be had from introducing elements of social and political philosophy to the teaching of skills and values, which happen before students go out on their first social work placement, typically carried out within small groups and seminars.

In the light of harsh welfare reform and economic recession, these students will end up working in settings with reduced financial resources. What parts of their learning will these social-workers-in-the-making draw on to decide who gets support and who does not? It is at this part of the coalface that I see philosophical understandings of concepts such as recognition and personhood as being crucial to the development of ethical and moral social work practice. So for example lkäheimo discusses the huge impact that 'seeing others as persons' (2008: 79) has on how one relates to that person; it is much easier to deny services or even abuse an 'it' if they are not recognised as a fellow human being. Students who understand the importance of recognition are 
likely to be more effective advocates for all groups of service users, not just disabled people.

To take these ideas further, it is not difficult to envisage the profound implications of getting students to debate questions such as those posed by another political philosopher Judith Butler, writing about the political times since the 9/11 attacks in New York in 2001:

'Who counts as human? Whose lives count as lives? And, finally, What makes for a grievable life?' (Butler, 2004: 20, emphasis in original)

Thinking about these questions is deeply unsettling and has the potential to cut straight to core assumptions and prejudices, exposing them for what they are. But it is vital that students understand the 'precarious' lives which those who need lifeextending treatment or social care packages have, because these decisions are informed by assumptions about quality of life.

'To say that life is precarious is to say that the possibility of being sustained relies fundamentally on social and political conditions, and not only on a postulated internal drive to live.' (Butler, 2010: 21)

One only has to consider the ongoing 'reform' of the welfare system which has targeted disabled people particularly aggressively, coupled with the public debates about assisted suicide, to see that life is indeed precarious for many disabled people - from the quality of life lived to the potential mode of death.

The benefits of having these discussions early on within the settings of small groups and seminars where social work skills, values and anti-oppressive practice are typically taught, means that the ground will then have been prepared for subsequent teaching about the particular issues faced by the diverse groups of people in society who might use the services of social workers. In the same way that the social model of disability is seen as a threshold concept (Morgan, 2012), discussions about recognition and grievable lives could also be seen as forming the portal for similar transformative learning.

\section{Conclusions}

Promoting philosophy as a part of learning for practice rather than academic rumination is not novel. For example, philosophy is being taught to students studying fine art as a way of improving their practice as described here by the lecturer:

'I have found that it is philosophy sessions and not art theory sessions that have stirred such a thinking-agency in the student artist ... and is perhaps the only way forward to truly realising 'Art'.' (H. Reeve, 2008: 8)

In a similar vein, I would suggest that introducing social work students to philosophy such as Honneth's theory of recognition has the potential to foster the development of students whose social work practice is truly ethical and moral. This would provide a sound bedrock on which to subsequently teach disability studies and to help ease the transition over the threshold marked by the social model of disability. This philosophical learning has an important part to play in developing true antioppressive 
practice and would benefit from being undertaken as part of the existing small group format teaching about skills and values that helps prepare students for their practice placements (Houston, 2009). Finally, Garrett (2010) raises concerns that teaching students about recognition risks raising their expectations about the actual impact they can have in tackling structural forms of misrecognition, because economic and political factors are not taken fully enough into account. However, in the case of psycho-emotional disablism which operates at the interpersonal micro level, then learning about recognition can nonetheless play a key part in improving the quality and outcomes of these working alliances between social work student and service user.

\section{References}

Abberley, P. (2002) 'Work, disability, disabled people and European social theory', in Disability Studies Today, eds C. Barnes, M. Oliver and L. Barton, Polity Press, Cambridge.

Butler, J. (2004) Precarious Life: The Powers of Mourning and Violence, Verso, London.

Butler, J. (2010) Frames of War: When is Life Grievable?, Verso, London.

Danermark, B. and Gellerstedt, L. C. (2004) 'Social justice: Redistribution and recognition--a non-reductionist perspective on disability', Disability \& Society, vol. 19, no. 4, pp. 339-353.

Fraser, N. and Honneth, A. (2003) Redistribution or Recognition? A PoliticalPhilosophical Exchange, trans. J. Golb, J. Ingram and C. Wilke, Verso, London. Garrett, P. M. (2010) 'Recognizing the limitations of the political theory of recognition: Axel Honneth, Nancy Fraser and social work', British Journal of Social Work, vol. 40, no. 5, pp. 1517-1533.

Honneth, A. (1995) The Struggle for Recognition: The Moral Grammar of Social Conflicts, trans. J. Anderson, Polity Press, Cambridge.

Honneth, A. (2001) 'Recognition or redistribution? Changing perspectives on the moral order of society', Theory, Culture \& Society, vol. 18, no. 2-3, pp. 43-55.

Houston, S. (2009) 'Communication, recognition and social work: Aligning the ethical theories of Habermas and Honneth', British Journal of Social Work, vol. 39, no. 7, pp. 1274-1290.

Houston, S. (2010) 'Beyond homo economicus: Recognition, self-realization and social work', British Journal of Social Work, vol. 40, no. 3, pp. 841-857.

Houston, S. and Dolan, P. (2008) 'Conceptualising child and family support: The contribution of Honneth's critical theory of recognition', Children \& Society, vol. 22, no. 6 , pp. 458-469.

Ikäheimo, H. (2008) 'Personhood and the social inclusion of people with disabilities', in Arguing about Disability: Philosophical Perspectives, eds K. Kristiansen, S. Vehmas and T. Shakespeare, Routledge, London.

Juul, S. (2009) 'Recognition and judgement in social work', European Journal of Social Work, vol. 12, no. 4, pp. 403-417.

Marthinsen, E. and Skjefstad, N. (2011) 'Recognition as a virtue in social work practice', European Journal of Social Work, vol. 14, no. 2, pp. 195-212.

Morgan, H. (2012) 'The social model of disability as a threshold concept:

Troublesome knowledge and liminal spaces in social work education', Social Work Education, vol. 31, no. 2, pp.??

Reeve, D. (2006) 'Towards a psychology of disability: The emotional effects of living in a disabling society', in Disability and Psychology: Critical Introductions and Reflections, eds D. Goodley and R. Lawthom, Palgrave, London.

Reeve, D. (2008) Negotiating Disability in Everyday Life: The Experience of PsychoEmotional Disablism, PhD Thesis, Lancaster University, Lancaster. 
Reeve, H. (2008) 'Head hunting art: The artist-philosopher and the value of incorporating philosophy within the education of practicing artists', The International Journal of the Arts in Society, vol. 2, no. 6, pp. 1-8.

Shakespeare, T. (2000) 'Disabled sexuality: Toward rights and recognition', Sexuality and Disability, vol. 18, no. 3, pp. 159-166.

Shakespeare, T. (2006) Disability Rights and Wrongs, Routledge, Abingdon.

Thomas, C. (1997) 'The baby and the bathwater: Disabled women and motherhood in social context', Sociology of Health \& IIIness, vol. 19, no. 5, pp. 622-643.

Thomas, C. (2007) Sociologies of Disability and Illness: Contested Ideas in Disability Studies and Medical Sociology, Palgrave Macmillan, Basingstoke.

Thompson, S. (2006) The Political Theory of Recognition: A Critical Introduction, Polity Press, Cambridge.

Watson, N. (2003) 'Daily denials: The routinisation of oppression and resistance', in Disability, Culture and Identity, eds S. Riddell and N. Watson, Longman, London. 